\title{
Afferent Connections of the Ectostriatum and Visual Wulst in the Zebra Finch (Taeniopygia guttata castanotis Gould) - an HRP Study
}

\author{
BARBARA E. NIXDORF* and HANS-JOACHIM BISCHOF \\ Universität Bielefeld, Fakultät für Biologie, Lehrstuhl für Verhaltensphysiologie, Morgenbrede 45, D-4800 Bielefeld, (F.R.G.)
}

(Accepted March 4th, 1982)

Key words: bird — zebra finch — tectofugal pathway — thalamofugal pathway — horseradish peroxidase tetramethylbenzedine

\begin{abstract}
Afferent connections of the two main areas in the telencephalon, the visual wulst and the ectostriatum, were traced in the zebra finch by injection of horseradish peroxidase and staining with tetramethylbenzidine (TMB). Nuclei projecting to the hyperstriatum accessorium (HA) or the HIS region (lamina hyperstriatica intercalatus superior) were: (1) ipsilaterally the $n$. dorsalis anterior pars lateralis (DLL) with its two subdivisions DLLd and DLLv, the n. dorsolateralis anterior pars magnocellularis (DLAmc), and the area pretectalis (AP); (2) bilaterally the nucleus of the septomesencephalic tract (SPC) with the ipsilateral component coming from the medial, the contralateral component from the lateral part of the nucleus. As in the pigeon or the owl the ectostriatum of the zebra finch receives massive input, which is topographically ordered, from the $n$. rotundus. In addition to this pathway the ectostriatum receives additional visual input from the ipsilateral area pretectalis, the $\mathrm{n}$. subrotundus and eventually a bilateral projection from the $\mathrm{n}$. tegmenti pedunculopontinus pars compacta (TPC).
\end{abstract}

\section{INTRODUCTION}

In birds as in other vertebrates one can distinguish between two different visual pathways: (1) the socalled thalamofugal projection, where visual information from the retina is relayed by nuclei of the dorsal thalamus to the visual wulst ${ }^{5,15,16}$, which may be homologous to the geniculo-cortical system of mammals ${ }^{10,29}$, and (2) the tectofugal pathway. The latter leads visual information from the retina to the tectum opticum (TO) of the mesencephalon, further to the $\mathrm{n}$. rotundus, the most prominent nucleus of the diencephalon, and then to the telencephalic station of this projection, the so-called ectostriatum $1,14,30,32$. This projection may be comparable with the mammalian pathway: retina - superior colliculus - pulvinar - extrastriate cortex ${ }^{10,14}$, 16,27 .

The principal wiring of these pathways has been well known for some time. Benowitz and Karten ${ }^{1}$ studied the afferent connections of the ectostriatum in pigeons by injection of horseradish peroxidase (HRP); they demonstrated a complex topographically ordered organization of the rotundo-ectostriatal pathway. Kimberley et al. ${ }^{17}$ and Cohen and Karten ${ }^{4}$ described some more inputs to the ectostriatal nucleus. The thalamic area projecting to the ipsi- and contralateral visual wulst ${ }^{9,16,18,21,22,24-26}$ has been called nucleus opticus principalis thalami (OPT, ref. 16). This nuclear mass is composed of several distinct nuclei, including the nucleus dorsolateralis anterior thalami (DLA) with its subunits pars magnocellularis (DLAmc) and pars lateralis (DLL). The latter can be further divided into a dorsal (DLLd) and a ventral part (DLLv).

The connections between OPT and wulst are not clear yet. Some features are generally accepted, such as e.g. the connection between the $\mathbf{n}$. dorsolateralis anterior pars lateralis ventralis (DLLv) and the ipsilateral hyperstriatum accessorium (HA), or between the DLLd and ipsi- and contralateral $\mathrm{HD}^{9,21,24}$. Others are still controversial as is the role of the

\footnotetext{
* Present adress: The Rockefeller University, New York, N.Y. 10021, U.S.A.
} 
nucleus of the septomesencephalic tract (SPC, n. superficialis parvocellularis). Some authors could demonstrate connections between this nucleus and the wulst area, while others failed to confirm these findings ${ }^{16,21}$.

In this study we have tried to add some more information about connections between the thalamic nuclei and the main visual telencephalic regions, and to broaden the basis for interspecific comparison by investigation of another species, the zebra finch (Taeniopygia guttata castanotis Gould), which has recently developed as a new standard object for behavioral and physiological research.

\section{MATERIALS AND METHODS}

A total of 30 adult zebra finch males from the institute's stock were used for this study. For the application of HRP they were anesthetized by $0.1 \mathrm{ml}$ Equithesin $(0.01 \mathrm{ml} / \mathrm{g}$ b.wt.), and mounted in a stereotaxic apparatus, especially designed for small birds ${ }^{2}$. HRP (Boehringer Type 1, 0.03-0.1 $\mu \mathrm{l}, 30 \%$ in $1 \%$ DMSO) was injected into the brain tissue at coordinates estimated by a stereotaxic atlas of the zebra finch brain (Bischof and Nixdorf, unpubl.) with a glass pipette, tip diameter of about $30 \mu \mathrm{m}$, which was glued to the tip of a $1 \mu \mathrm{l}$ microsyringe. The tip was left in position after the injection for about 20 min. Survival time was $24 \mathrm{~h}$. The birds were then anesthetized with $0.03 \mathrm{ml}$ Nembutal, perfused via the left ventricle with a $0.9 \% \mathrm{NaCl}$ solution for 15 min, followed by 10 min with $1.25 \%$ glutaraldehyde, $1 \%$ paraformaldehyde in $0.1 \mathrm{M}$ phosphate buffer ( $\mathrm{pH} \mathrm{7.4),} \mathrm{and} \mathrm{another} 10 \mathrm{~min}$ with the same solution to which $30 \%$ glucose was added.

After removal of the brain the tissue was stored in a fixative-sucrose solution overnight, until the brain had sunk to the bottom of the jar.

The brain was blocked with the help of a stereotaxic apparatus and cut on a freezing microtome in the transverse stereotaxic plane in $30 \mu \mathrm{m}$ sections. Every third section was stored in $0.1 \mathrm{M}$ phosphate buffer, $\mathrm{pH} 7.4$, processed with tetramethylbenzidine according to the method of Mesulam ${ }^{23}$, and counterstained with neutral red, fixed to a coverslip with Canada balsam (Merck, artificial) and examined with bright- and dark-field microscopy.

Identification of the different nuclei was obtained by comparing our results with the stereotaxic atlas of the pigeon ${ }^{13}$, and that of the canary ${ }^{33}$.

As the ectostriatum of the zebra finch is very small (about $1.2 \mathrm{~mm}^{3}$ ) it was not possible to inject selectively into very small distinct parts of the nucleus. We succeeded, however, in differentiating between rostral, medial and caudal injections. Occasionally we happened to inject only lateral parts or regions at the medial boundary. If involvement of the surrounding areas (paleostriatum augmentatum, tractus fronto-archistriatalis, neostriatum) was observed, the brains were rejected from interpretation.

Our wulst injections were limited to the hyperstriatum accessorium (HA) in all experiments, in some cases with possible diffusion into the hyperstriatum intercalatus superior (HIS). Sometimes we were not able to decide exactly whether HIS was labeled or not. This effect was due to the diffusion of the enzyme which makes it impossible to define sharp boundaries of the injection. The hyperstriatum dorsale, however, was free of visible HRPlabeling in all cases.

\section{RESULTS}

\section{Thalamofugal pathway}

The architecture of the OPT complex as well as the hyperstriatum of the zebra finch is very similar to that of the pigeon (see Introduction). Nuclei of the thalamic region are clearly distinguishable in Nissl sections and silver impregnations, and are not as densely packed as in the owl. As in the pigeon the hyperstriatum of the zebra finch can be divided into 3 layers: hyperstriatum accessorium (HA), hyperstriatum intercalatus superior (HIS) and hyperstriatum dorsale (HD). The hyperstriatum accessorium receives fibers from the following thalamic nuclei, as revealed by injection of horseradish peroxidase:

$D L A$. With injections into the hyperstriatum accessorium the dorsal and the ventral part of the $n$. dorsolateralis anterior, pars lateralis (DLLd and DLLv) were labeled at the ipsilateral side (Fig. 1). No contralateral labeling occurred. DLLd is situated just beside the medial part of the nucleus of the septomesencephalic tract (SPC); however, both nuclei could easily be distinguished, as DLLd contains neurons of much smaller size than SPC. The ventral part of DLLd seems to be stained more intense than 


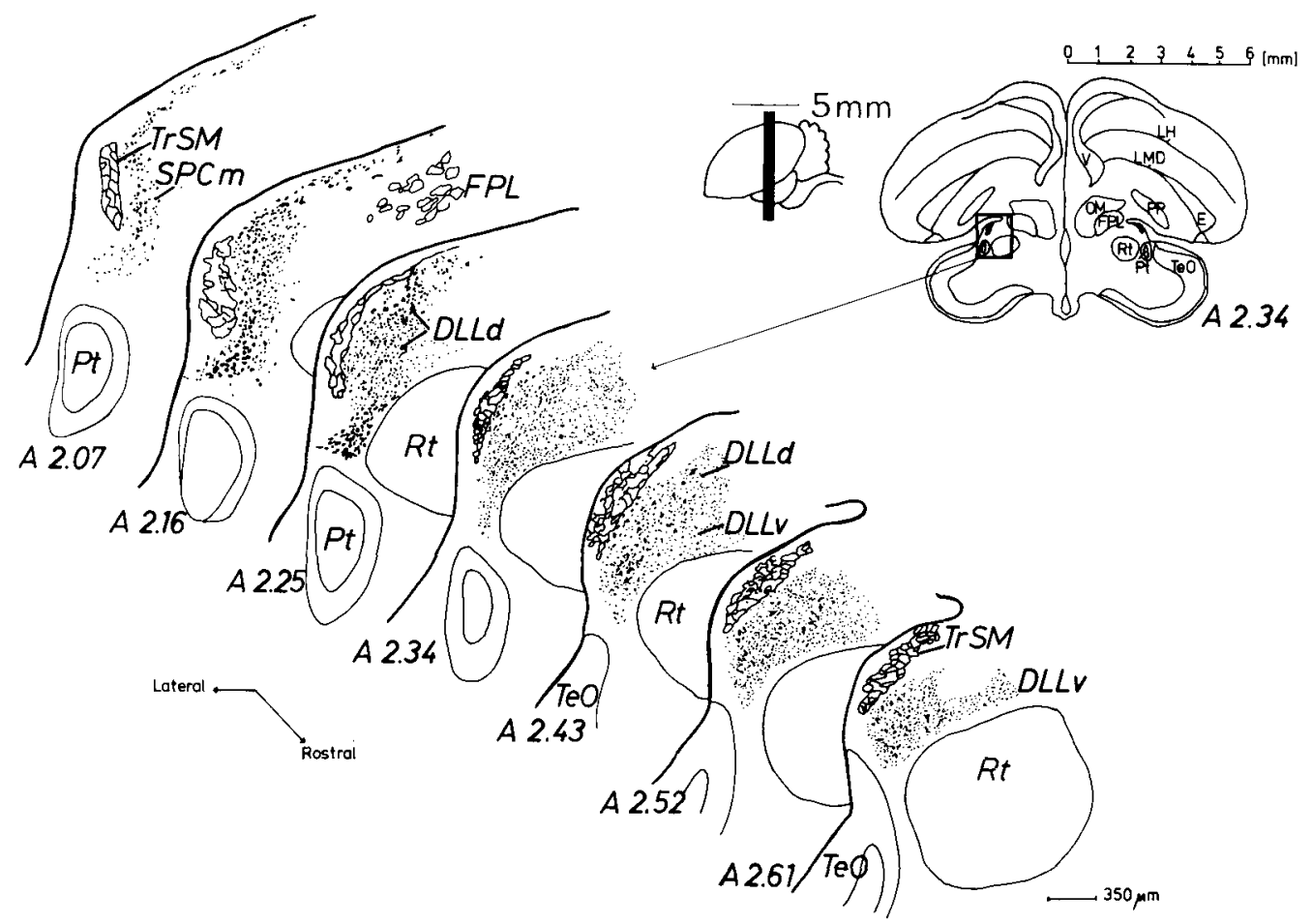

Fig. 1. Distribution of HRP-labeled cells in the $\mathrm{n}$. dorsolateralis pars ventralis (DLLv) and pars dorsalis (DLLd).
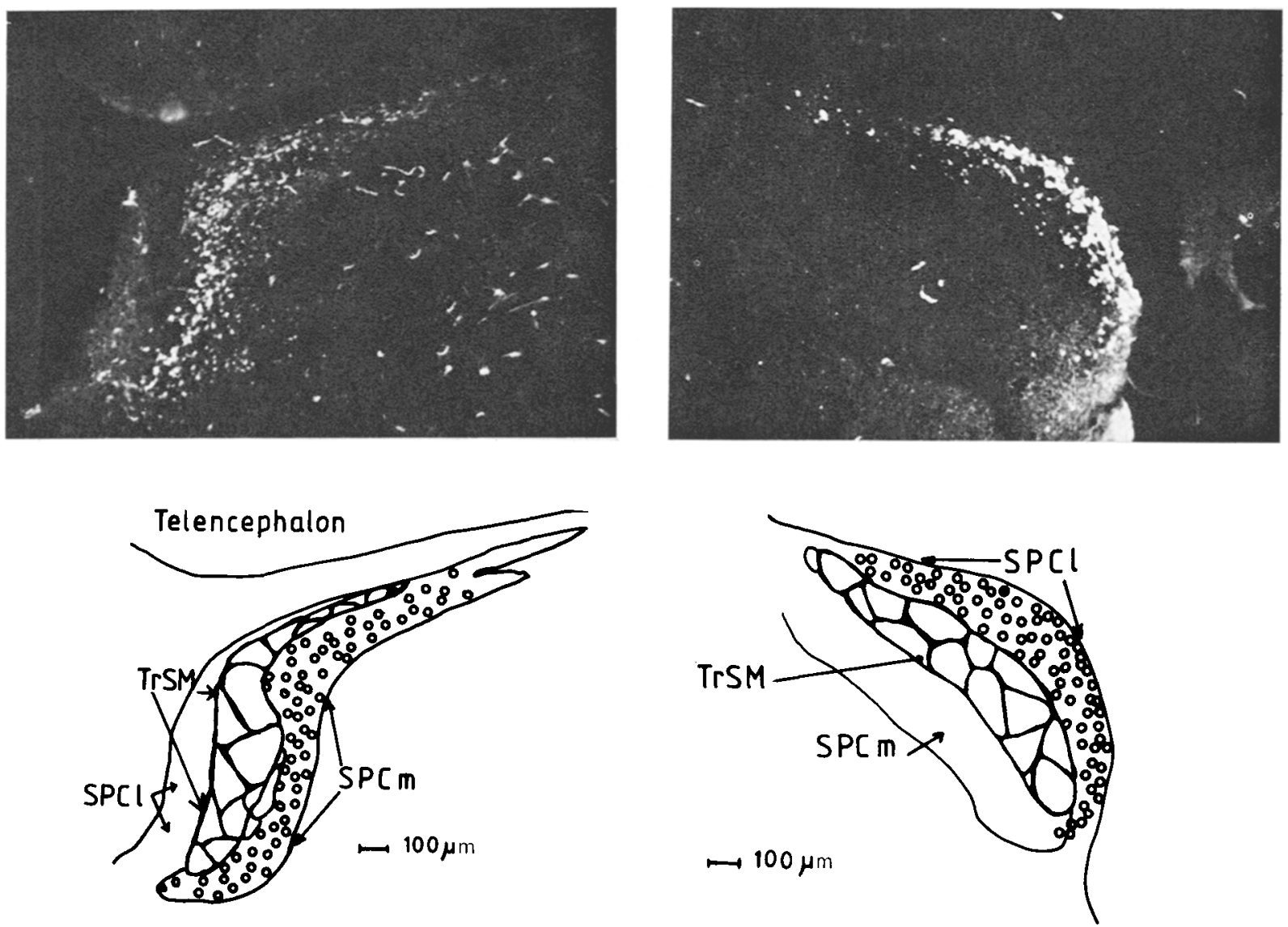

Fig. 2. HRP-labeled cell bodies in the SPC. Left: ipsilateral side. Labeling occurs only in the medial part of the nucleus (SPCm). Right: contralateral side. HRP granula are visible solely in the cells of the lateral part. TrSM, tractus septomesencephalicus. 


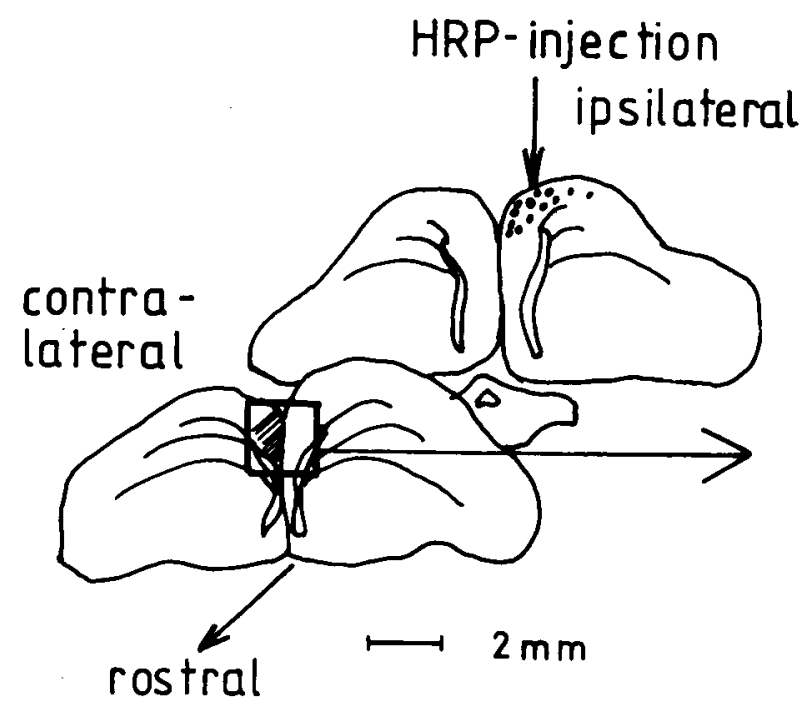

Fig. 3. Area of labeled cells in the contralateral HA.

the dorsal part, indicating that this nucleus can be further divided into subunits, as suggested by histological and electrophysiological data ${ }^{24}$.

$A P$. The visual function of the area pretectalis (AP) has been considered in two papers ${ }^{7,15}$. We found HRP-labeled cells in all injections. They were diffusely distributed mainly in the rostral part of the area. The caudal part, however, was also slightly stained.

$S P C$. The nucleus of the septomesencephalic tract or n. superficialis parvocellularis (SPC) is located at the very edge of the dorsolateral thalamus, and forms a tube-like structure round the septomesencephalic tract (TrSM). In frontal sections one can separate two distinct portions of the nucleus, a lateral and a medial component. Fig. 2 demonstrates the results of injection of HRP into the hyperstriatum accessorium. By these injections the medial part of the nucleus is labeled ipsilaterally, whereas at the contralateral side only the lateral part of the nucleus contains HRP reaction product.

$H A$. Although we found this wulst-wulst projec-

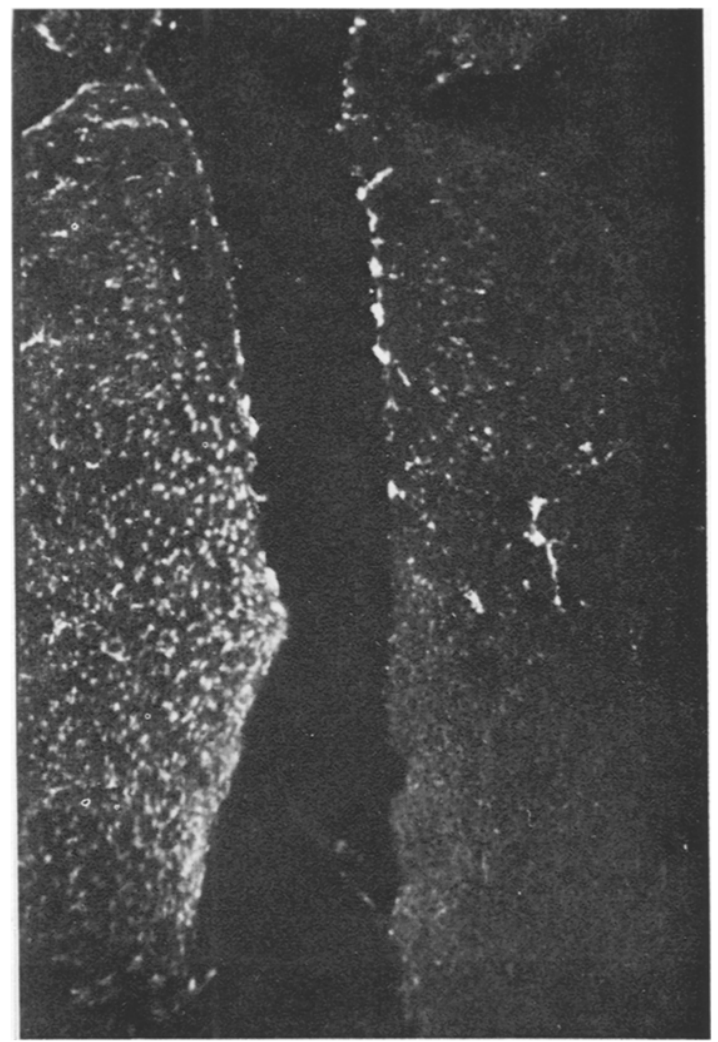

tion only in one case, we would like to draw attention to this result, as it would demonstrate a direct route from one hemisphere to the contralateral one, not relayed by the thalamic nuclei, a path which has not been demonstrated before. The labeled area is situated at the most ventral part of the HA, inside the angle built by the boundaries of the brain midline and the telencephalic ventricle (Fig. 3). In the rostrocaudal plane it occupies an area of $400 \mu \mathrm{m}$, just contralateral to the injection site. It seems unlikely that this labeling is an artifact of diffusion of HRP from one hemisphere to the other, independent of nerve structures, as the staining was found to be concentrated to cell bodies, and the labeled cells form a clear patch with relatively sharp boundaries. There is some evidence now that the fibers connecting the two areas do not pass through the decussatio supraoptica (DSO) but cross by the commissura pallii (CP, Karten, pers. comm). We cannot decide this question, as we got stained fibers in both commissural connections.

In addition to nuclei which are known to belong 
to the visual system, we could detect HRP-labeled cell bodies in the following thalamic nuclei: nucleus dorsolateralis posterior thalami (DLP), n. intermedius posterior thalami (DIP), tractus occipitomesencephalicus (OM), HOM (OM, pars hypothalami, which is a separate fiber bundle in spite of its name). All these areas were labeled ipsilaterally. Bilateral labeling was only obtained in one case in DIP.

\section{Tectofugal pathway}

Independent of the localization within the ectostriatum, labeled cells were found in the area pretectalis (AP), n. subrotundus (SRt), and n. rotundus (Rt). Within the latter nucleus different areas, depending on the injection site, were observed, the pattern of which will be described later. With caudal ectostriatum injections labeling was observed in the n. tegmenti pedunculo-pontinus pars compacta (TPC), n. sensorius principalis nervi trigemini (PRV) and $n$. ventralis lemnisci lateralis (VLV). Occasionally, labeling of the $n$. subpretectalis (SP), $n$. interstitio-pretecto-subpretectalis (IPS) and n. spiriformis lateralis (SPL) was found. Fibers of the supraoptic decussation (DSO) were stained in two preparations.

$N$. rotundus. Analysis of the rotundal projection of the zebra finch demonstrates a high degree of similarity between our results and those obtained in the pigeon ${ }^{1}$. Distinct areas within the $\mathrm{n}$. rotundus project to different parts of the ectostriatum. Rostral injections labeled about $60 \%$ of the nuclear mass, particularly the $\mathrm{n}$. triangularis and the caudal part of the rotundus. With more precise investigation it appears that $\mathrm{n}$. triangularis labeling occurs in rostrolateral injections; rostromedial ones are followed by labeling of a wedge-shaped area in the medial part of the rotundus (Fig. 4).

Cells with HRP reaction product were seen in all parts of the rotundus and in the nucleus triangularis, if the injection site was in the caudal part of the ectostriatum. In these injections it is possible to identify a clearly distinguishable portion of cells in the ventral part of the rotundus, which is the source of the majority of all fibers leaving the nucleus. Fibers of the ventrolateral portion of these cells are tracking through the whole nuclear mass and leave the area at its dorsal boundary, forming there a

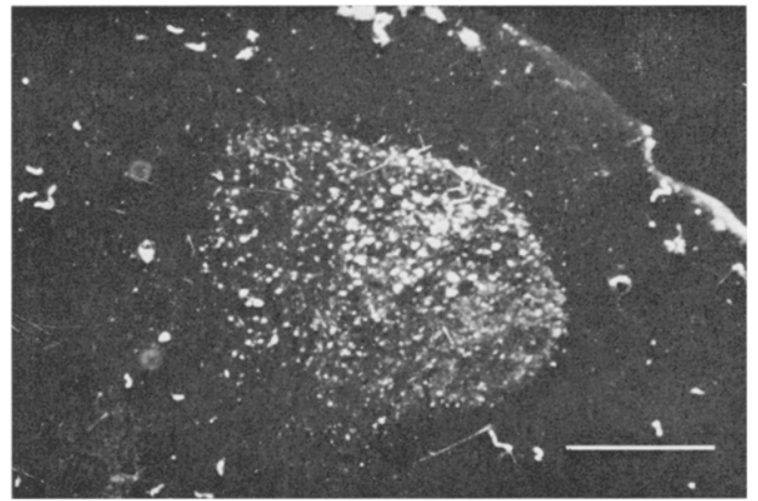

Fig. 4. Rostromedial injection into the ectostriatum yielded labeling of a wedge-shaped portion of larger cells in the medial part of rotundus. Dark-field micrograph, transverse section, bar $=500 \mu \mathrm{m}$.

component of the fasciculus prosencephali lateralis (FPL, Fig. 5). Efferents of the ventromedial region, however, leave the nucleus at the lateral side to join the FPL (Fig. 6). The destination of these fibers is the mediocaudal region of the ectostriatum. Additional fiber outputs are observed at the dorsolateral and the dorsomedial boundaries of the nucleus (Fig. 5).

Area pretectalis. This region was labeled in $90 \%$ of all experiments. In caudal injections two subdivisions of the nucleus were visible, a dorsal part with large cell bodies, and a smaller ventral part with small cells (Fig. 7).

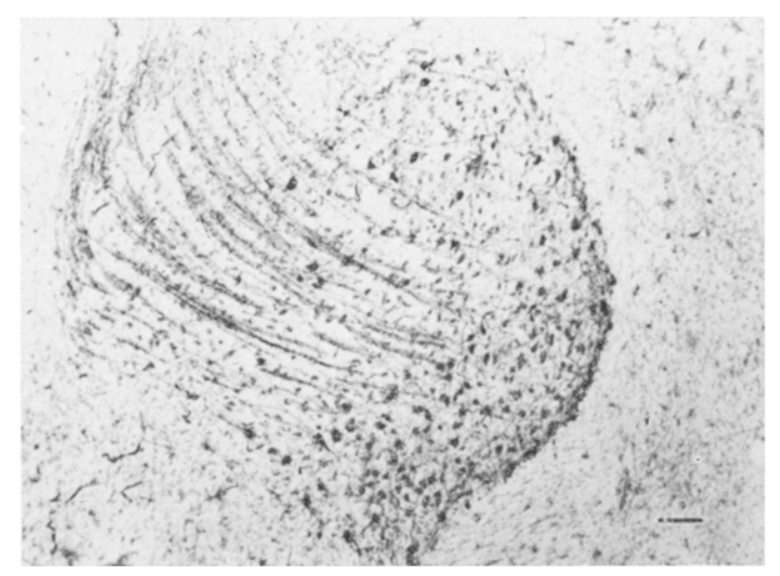

Fig. 5. Cells in the ventral portion of the rotundus as revealed by caudolateral injections. Fibers tracking through the nuclear mass to the lateral forebrain bundle. Bright-field micrograph, bar $=100 \mu \mathrm{m}$. 


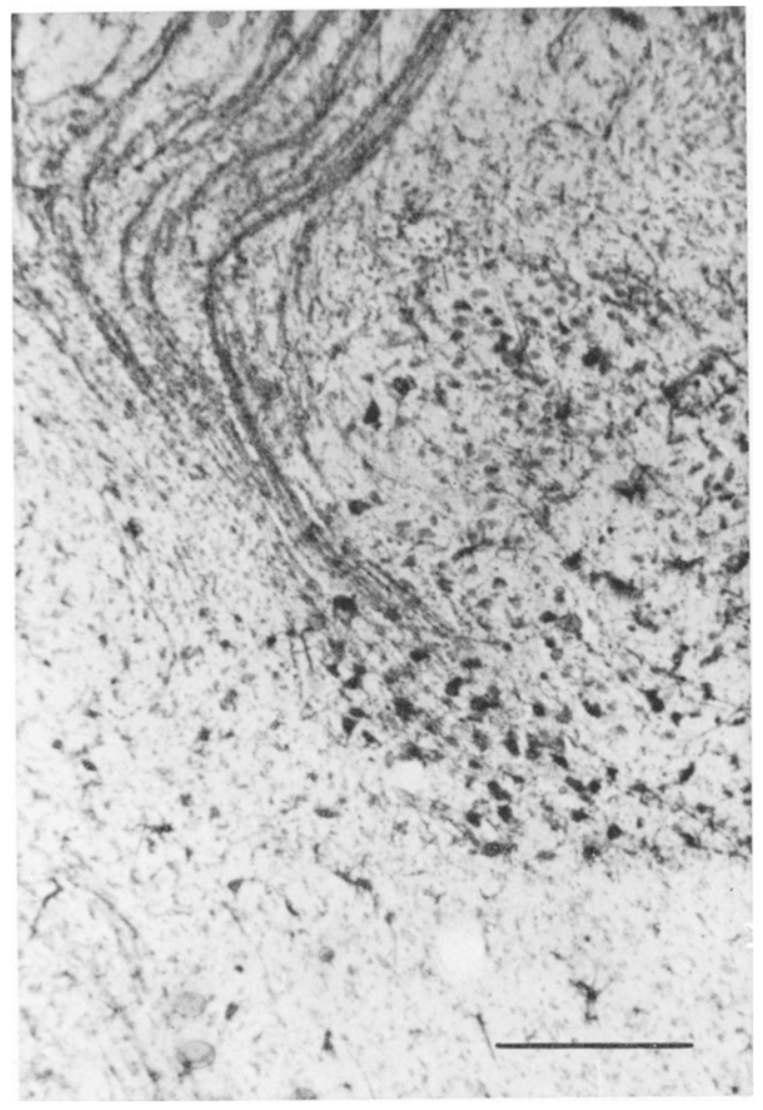

Fig. 6. Labeled cells in the ventromedial part of the rotundus. Fibers are tracking to the medial boundary of the nucleus to join the lateral forebrain bundle. Bright-field micrograph, bar $=100 \mu \mathrm{m}$.

Bilateral projections. Of the other labeled nuclei only two will be mentioned here, since they seem to project bilaterally, namely the $\mathrm{n}$. ventralis lemnisci

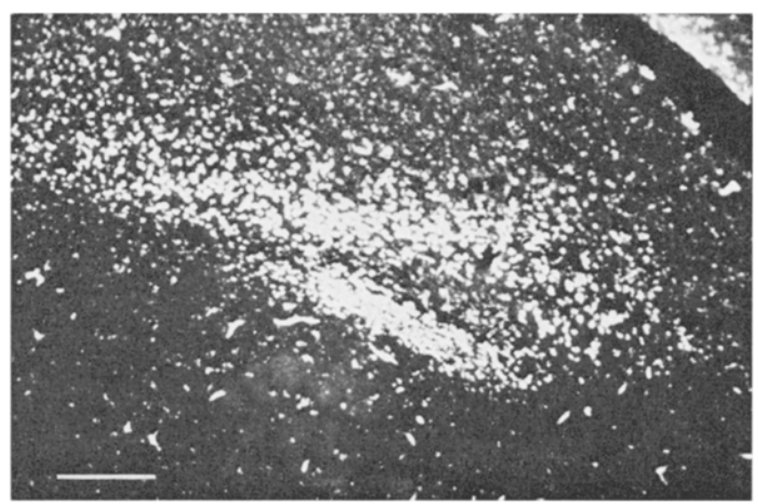

Fig. 7. Area pretectalis. Two subdivisions of cells divided by a narrow strip of unlabeled cells dorsal to the posterior commissure (Cp). Transverse section, dark-field micrograph, bar $=250 \mu \mathrm{m}$. lateralis (VLV) and $\mathrm{n}$. sensorius principalis trigemini (PRV), both situated in the medulla. Labeling occurred in all caudal ectostriatum injections. In combination with occasionally observed staining of the decussatio supraoptico (DSO) these results demonstrate that the ectostriatum may not only process ipsilateral information.

\section{DISCUSSION}

\section{Thalamofugal pathway}

Studies of the connections between single thalamic nuclei and the different wulst regions were carried out mainly in pigeons $s^{9,16,18,21,22,24-26}$. There are some differences in the results of recent reports, but they are not really controversial, and with a few exceptions, can be combined (Fig. 8). All authors ${ }^{9,21}$, 24 demonstrate ipsilateral projections from the $n$. dorsolateralis anterior pars lateralis (DLL) to the hyperstriatum accessorium (HA) and hyperstriatum dorsale (HD), and contralateral projections from the dorsal part of that nucleus (DLLd) to HD. The ipsilateral projections are confirmed by the present study; HD projections were not investigated here.

The role of SPC is unclear. No projections direct-

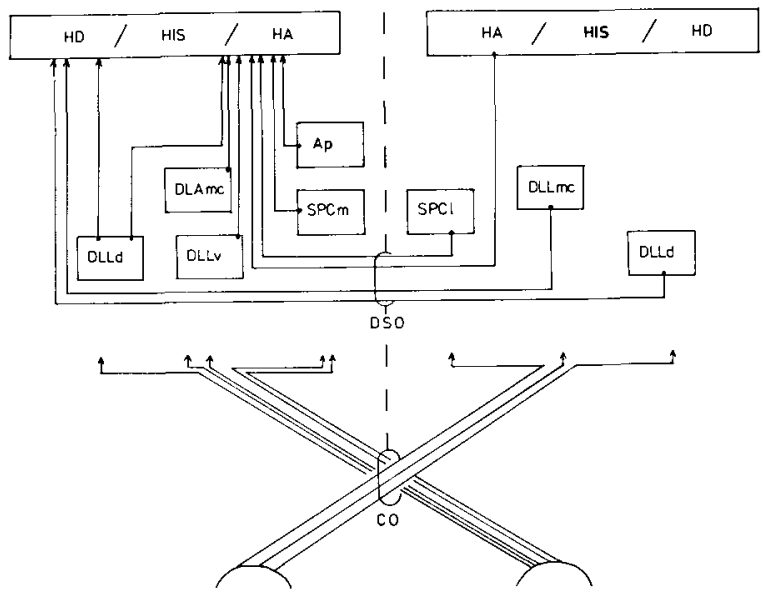

Fig. 8. Schematic diagram of the connections of the thalamofugal pathway combined from the results of different authors and the present study. For the sake of simplicity only the inputs of one hemisphere are drawn. Combined from the results of refs. 9, 21 and 24, and the present report. Abbreviations: HA, hyperstriatum accessorium; HIS, lamina hyperstriatica intercalata superior; HD, hyperstriatum dorsale; DLLd (DLL) pars dorsalis anterior pars; DLLv (DLL), pars ventralis; DLLmc (DLL), pars magnocellularis; DLAme, n. dorsolateralis anterior pars magnocellularis; $\mathrm{SPC}$, n. superficialis parvocellularis medialis; $\mathrm{SPCl}$, pars lateralis; AP, area pretectalis; DSO, decussatio supraoptico; CO, chiasma opticum. 
ly from the retina have been demonstrated by histological techniques ${ }^{21,22,24}$. Responses to visual stimuli, however, were obtained in SPC by electrophysiological experiments ${ }^{19}$, so we can declare this nucleus to be visual. Connections of this nucleus to the hyperstriatum have been demonstrated ${ }^{9}$, but the distinction of two different parts with different projections as revealed by this study has not been mentioned before. Unfortunately, there are no investigations available concerning the topology of the projection to that area. Nevertheless, it is tempting to speculate that the information from the eye may be split in this relay station, e.g. by leading the information of one hemifield of the visual space to the contralateral hemisphere (via lateral SPC) and the information of the other hemifield to the ipsilateral side (via medial SPC), as proposed by Pettigrew and Konishi ${ }^{29}$ for the owl thalamic relay. It seems to be important that both parts of the SPC project to the same part of the hyperstriatum: only in such a configuration would direct convergence of the input of the two eyes to binocularly driven cells be possible. The other parts of the OPT complex seem to project mainly to different parts of the hyperstriatum; DLLd pars ventralis and DLLv project ipsilateral to HA/HIS, a result supported by our data. DLLd pars dorsalis and DLLmc seem to project mainly to the contralateral $\mathrm{HD} / \mathrm{HIS}^{24}$, the only overlap of these two projections can be seen in HIS, and it remains unclear whether this overlap is true or must be regarded as an artifact. However, DLLd seems to project to some extent ipsi- and contralaterally to $\mathrm{HD}^{9,21}$, and therefore this projection might also be designed for direct binocular comparison. It seems unlikely that this is really the case, as the electrophysiological results demonstrate that binocularity, whenever found, was restricted to $\mathrm{HA}^{28,29}$. If one accepts the similarity of the thalamofugal projection of birds with the geniculo-cortical system of mammals ${ }^{29}$, where the information of the two hemifields of the eyes are represented each in the contralateral hemisphere of the cortex, the above demonstrated HA-HA projection would make sense as a functional analogue of the corpus callosum of mammals.

The projection from the area pretectalis will be discussed below, as this region gets additional input from the ectostriatum.

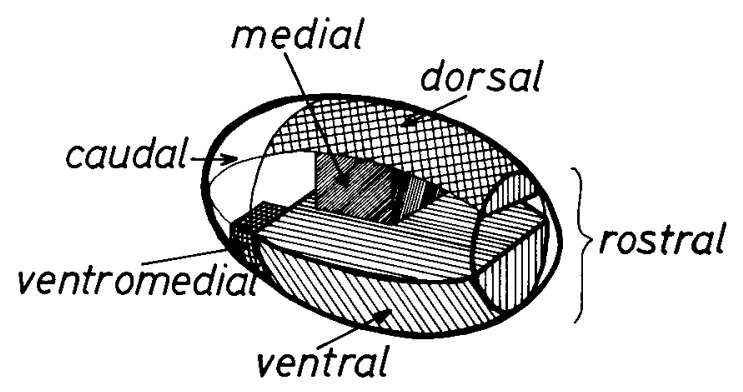

Fig. 9. Schematic diagram of the subdivisions of rotundus as revealed by injection of HRP into different ectostriatal regions. Explanations see text.

\section{Tectofugal pathway}

Our histological results concerning the rotundoectostriatal connections are in good agreement with the results obtained in the pigeon ${ }^{1}$. The nucleus can be divided into a caudal, medial, dorsal and ventral component by means of HRP injection into different parts of the ectostriatum (Fig. 9). In addition to the results of Benowitz and Karten ${ }^{1}$ we could identify a group of large cells in the ventral region of the nucleus, the axons of which pass through the rotundus and leave the nucleus at its dorsal boundary (Fig. 5).

Recent morphological and physiological results are only in part consistent $1,6,19,31$. The dorsal and ventral zones have been identified in all studies. The caudal area identified by histology also has a physiological correlate ${ }^{31}$. The medial part found in this study has not yet been established in electrophysiological experiments.

Projections of the different parts of the rotundus are similar in our results and those obtained by other authors ${ }^{1}$ : medial regions of the rotundus project to medial parts of the ectostriatum, ventral areas to lateral, caudal regions to the whole ectostriatum, and ventromedial caudal rotundal areas to the mediocaudal ectostriatum.

Of the other nuclei we have found labeled in our experiments, two are expected to be visual, viz. the area pretectalis ${ }^{7,15}$ and the $n$. subrotundus ${ }^{8}$, as they receive input from the retina. The area pretectalis may be another example of a connection between the thalamofugal and the tectofugal pathways. We also found labeled cells in this area by injection of HRP into the hyperstriatum accessorium. As the 
distribution of cells is different in the two studies (injection into the ectostriatum causes two subdivisions of labeled cells, whereas in HA injections the cells were evenly spread over the whole area), there may in fact be different portions of cells projecting to one or the other telencephalic station. The function and significance of this connection cannot be speculated about yet.

The role of the remaining nuclei (TPC, SP, IPS, SPL) is not as clear. They are situated in the ventral thalamus and therefore one can suppose that they are not comparable to the dorsal thalamic nuclei relaying information from sensory organs to telencephalic fields. Recent studies ${ }^{3,12}$ indicate projections of these nuclei to the paleostriatal complex

\section{REFERENCES}

1 Benowitz, L. I. and Karten, H. J., Organisation of the tectofugal pathway of the pigeon: a retrograde transport study, J. comp. Neurol, 167 (1976) 503-520.

2 Bischof, H.-J., A stereotaxic headholder for small birds, Brain Res. Bull., 7 (1981) 335-336.

3 Brauth, S. E., Ferguson, J. L. and Kitt, C. A., Prosencephalic pathways related to the palaeostriatum of the pigeon (Columba livia), Brain Research, 147 (1978) 205-221.

4 Cohen, D. H. and Karten, H. J., The structural organisation of the avian brain: an overview. In I. J. Goodman and M. W. Schein (Eds.), Birds, Brain and Behaviour, Academic Press, New York, 1974, pp. 29-73.

5 Cowan, W. M., Adamson, L. and Powell, T. P. S., An experimental study of the avian visual system, J. Anat. 95 (1961) 545-562.

6 Granda, A. M. and Yazulla, S., The spectral sensitivity of single neurons in the nucleus rotundus of the pigeon, Columba livia, J. gen. Physiol., 57 (1971) 363-384.

7 Hodos, M. and Bonbright, J. C., Intensity and pattern discrimination after lesions of the pretectal complex, accessory optic nucleus and ventral geniculate in pigeons, J. comp. Neurol., 161 (1975) 1-18.

8 Hunt, S. P. and Kuenzle, H., Observations of the projections and intrinsic organisation of the pigeon optic tectum: an autoradiographic study based on anterograde and retrograde, axonal and dendritic flow, J. comp. Neurol., 170 (1976) 153-172.

9 Hunt, S. P. and Webster, K. E., Thalamo-hyperstriatal interrelations in the pigeon, Brain Research, 44 (1972) 647-651.

10 Karten, H. J., The organisation of the avian telencephalon and some speculations on the phylogeny of the amniote telencephalon, Ann. N.Y. Acad. Sci, 167 (1969) 167-179.

11 Karten H. J., Efferent projections of the wulst of the owl, Anat. Rec., 169 (1971) 353.

12 Karten, H. J. and Dubbeldam, J. L., The organisation and the projections of the palaeostriatal complex in the pigeon (Columba livia), J. comp. Neurol., 148 (1973) 61-90.

13 Karten, H. J. and Hodos, W., A Stereotaxic Atlas of the
(PC). In the case of SP, IPS, and SPL we are not sure whether diffusion to $\mathrm{PC}$ or other surrounding areas may be responsible for the labeling of the nuclei; we found no indication for such diffusion, but labeling of these nuclei was observed in only one case in our experiments.

\section{ACKNOWLEDGEMENTS}

The authors are grateful to Prof. H. J. Karten for a discussion of our results and to Prof. K. Immelmann for his interest in this research. Mrs. E. Geissler provided excellent technical assistance. We also thank Dr. M. Reddington for carefully reading the manuscript.

Brain of the Pigeon (Columba livia), Johns Hopkins, Press, Baltimore, MD, 1967.

14 Karten, H. J. and Hodos, W., Telencephalic projections of the nucleus rotundus in the pigeon (Columba livia), $J$. comp. Neurol., 140 (1970) 35-52.

15 Karten, H. J. and Nauta, W. H. J., Organization of retinothalamic projections in the pigeon and the owl, Anat. Rec., 160 (1968) 373.

16 Karten, H. J., Hodos, W., Nauta, W. H. J. and Revzin, A. M., Neural connections of the 'visual wulst' of the avian telencephalon. Experimental studies in the pigeon (Columba livia) and the owl (Speotyto cunicularia), J. comp. Neurol., 150 (1973) 253-277.

17 Kimberley, R. P., Holden, A. L. and Bamborough, P., Response characteristics of pigeon forebrain cells to visual stimulation, Vision Res., 11 (1971) 465-478.

18 Lehmkuhle, S., Casagrande, V. A. and Fox, R., Bilateral retino-wulst projections in falcon revealed by transneuronal transport of ${ }^{3} \mathrm{H}$ proline, Neurosci. Abstr., 3 (1977) 567.

19 Maxwell, J. H. and Granda, A. M., Receptive fields of movement-sensitive cells in the pigeon thalamus. In A. M. Granda and J. H. Maxwell (Eds.), Neural Mechanisms of Behavior in the Pigeon, Plenum Press, New York, 1979, pp. 177-197.

20 Meier, R. E., Dalderup, J. and Cuenod, M., A visual function of the supraoptic decussation in the pigeon, Experientia, 26 (1970) 682.

21 Meier, R. E., Mihailowic, J. and Cuenod, M., Thalamic organisation of the retino-thalamo-hyperstriatal pathway in the pigeon (Columba livia), Exp. Brain Res., 19 (1974) 351-364.

22 Meier, R. E., Mihailowic, J., Perisic, M. and Cuenod, M., The dorsal thalamus as a relay in the visual pathways of the pigeon, Experientia, 28 (1972) 730.

23 Mesulam, M. M., Tetramethylbenzidine for horseradish peroxidase neurohistochemistry: a noncarcinogenic blue reaction product with superior sensitivity for visualizing neural afferents and efferents, J. Histochem. Cytochem., 26 (1978) 106-117.

24 Miceli, D., Perichoux, J. and Reperant, J., The retinothalamo-hyperstriatal pathway in the pigeon (Columba 
livia), Brain Research, 100 (1975) 125-131.

25 Miceli, D., Gioanni, H., Reperant, J. and Perichoux, J., The avian visual wulst. I. An anatomical study of afferent and efferent pathways. In A. M. Granda and J. H. Maxwell (Eds.), Neural Mechanisms of Behaviour in the Pigeon, Plenum Press, New York, 1979, pp. 223-236.

26 Mihailovic, J., Perisic, M., Bergonzi, R. and Meier, R. E., The dorsolateral thalamus as a relay in the retino-wulst pathway in the pigeon (Columba livia), Exp. Brain Res., 21 (1974) 229-240.

27 Nauta, W. J. H. and Karten, H. J., A general profile of the vertebrate brain with sidelights on the ancestry of cerebral cortex. In F. O. Schmitt (Ed.), The Neurosciences: Second Study Program, Rockefeller Press, New York, 1970, pp. 7-26.

28 Perisic, M., Mihailovic, J. and Cuenod, M., Electrophysiology of contralateral and ipsilateral visual projections to the wulst in pigeon (Columba livia), Int. J. Neurosci.,
(1971) 7-14.

29 Pettigrew, J. D. and Konishi, M., Neurons selective for orientation and binocular disparity, Science, 193 (1976) 675-678.

30 Revzin, A. M., Unit responses to visual stimuli in the nucleus rotundus of the pigeon, Fed. Proc., 26 (1967) 656.

31 Revzin, A. M., Functional localization in the nucleus rotundus. In A. M. Granda and J. H. Maxwell (Eds.), Neural Mechanisms of Behavior in the Pigeon, Plenum Press, New York, 1979, pp. 165-175.

32 Revzin, A. M. and Karten, H. J., Rostral projection of the optic tectum and the nucleus rotundus in the pigeon, Brain Research, 3 (1966) 264-276.

33 Stokes, T. M., Leonard, C. M. and Nottebohm, F., The telencephalon, diencephalon and mesencephalon of the canary, Serinus canaria, in stereotaxic coordinates, $J$. comp. Neurol., 156 (1972) 357-374. 